\title{
PSZICHOLÓGIA \\ A DEBRECENI TUDOMÁNYEGYETEMEN A XX. SZÁZAD ELSŐ FELÉBEN
}

\author{
MUDRÁK JÓZSEF \\ DE NK Magatartástudományi Intézet - DE Kenézy Orvostörténeti Múzeum \\ E-mail: mudrak.jozsef@unideb.hu
}

Beérkezett: 2014. június 17. - Elfogadva: 2014. augusztus 13.

\begin{abstract}
A Debreceni Tudományegyetemen már a XX. század elsö felében mind a Bölcsészettudományi Karon, mind az Orvostudományi Karon magas szintü pszichológiai kutatás folyt, és a korabeli oktatásba is be tudtak vinni pszichológiai jellegü kurzusokat.

Az ideg-és elmeklinika professzora, Benedek László a Magyar Pszichológiai Társaság elnöke volt 1931-1939 között, míg a társaság egyik alelnöki tisztét a debreceni pedagógiaprofesszor, Mitrovics Gyula töltötte be. A Mitrovics után következő Karácsony Sándor pszichológiai rendszere ma is élénken foglalkoztatja a tudományos világot. A tanszéki beosztottak közül Karácsony Sándor magántanára, Kiss Tihamér a gyermeklélektan müvelöje és Piaget egyik első magyarországi népszerüsitöje volt. Benedek magántanára, Máday István pedig a magyar individuálpszichológia megteremtöje és Adler legfontosabb tanítványának számítható.

Mindezek azt mutatják, hogy a XX. század elsö felében a pszichológia müvelésében Debrecen nem maradt el más kultúrközpontok mögött.
\end{abstract}

Kulcsszavak: magyar pszichológiatörténet, Debrecen, Debreceni Egyetem, Mitrovics Gyula, Benedek László, Karácsony Sándor, Kiss Tihamér, Máday István, Pap Zoltán 
Noha a Debreceni Egyetemen a pszichológia tudománya szervezett formában, önálló tanszékkel csak 1970-től van jelen, az előzmények jóval messzebbre mutatnak, az egyetem megszervezése (1914) utáni időkben már fellelhetőek nyomai. Mégpedig két különböző irányból fejlődik a pszichológia kutatása és oktatása.

Egyik részről vannak az ismertebb bölcsészkari előzmények: a Bölcsészettudományi Karon Mitrovics Gyula és Karácsony Sándor pedagógiaprofesszorok ez irányú tevékenysége, majd a kommunista korszakban Jausz Béla próbálkozása, és végül Kelemen László munkássága, amely az önálló Pszichológiai Tanszék megalakulásához vezetett.

Kevésbé ismert az orvoskari irányvonal, ahol elsősorban Benedek László ideggyógyász professzor járult hozzá a pszichológia fejlődéséhez az egyetemen. A két irányvonal fejlődése nem volt egymástól független, Benedek és Mitrovics nemcsak ismerték egymást, hanem munkakapcsolat is volt közöttük, kooperációjuk tovább erősítette az akkor még fontosnak tartott „,egységes egyetem” szellemiségét. Ádám Péter és Tóth László 1994-es összefoglalója csak a bölcsészeti előzményekről szól, az orvoskariról nem vesz tudomást.

A pszichológia művelése és oktatása Debrecenben - ahogyan a többi egyetemen is - a bölcsész részen a Filozófiai és a Neveléstudományi Tanszékekhez, az orvosi részen az Ideg- és Elmegyógyászati Tanszékhez kapcsolódik.

\section{PSZICHOLÓGIA MAGYARORSZÁGON A XX. SZÁZAD ELSŐ FELÉBEN}

A pszichológia Magyarországon a XIX. században jelent meg mint filozófiai pszichológia, elsősorban Pekár Károly, Pauer Imre, Posch Jenő, Böhm Károly írásait lehet felemlíteni. Ugyanakkor az orvosi hátterű pszichológiai tanulmányok is jelen voltak, Moravcsik Ernő Emil, Lechner Károly és Ranschburg Pál lélektannal foglalkozó tanulmányai révén (KIss, 1995, 16-17).

A fellendülés Ranschburg Pálhoz köthető, aki 1899-ben a budapesti egyetemi orvoskari Pszichiátriai Klinikán megszervezte a lélektani laboratóriumot, de ez inkább patologikus lelki esetekkel foglalkozott. A vizsgálatokra támaszkodó, kísérleti pszichológia egyetemi oktatási keretekbe való beillesztése Révész Géza érdeme volt, aki 1908-tól a kísérleti lélektan magántanára a bölcsészkaron, majd 1918-ban kinevezték professzorrá, és megszervezhette tanszékét.

Az első világháborút követő forradalmak után visszaesés következett be a hazai pszichológiában, számos prominense és ezen keresztül maga a tudomány is diszkreditálódott, Révész Géza Hollandiába emigrált, a többiek (Ferenczi Sándor, Nagy László) itthon perifériára kerültek.

Az egyetemek bölcsészkarain a harmincas évekre fejlődött ki újra a pszichológia oktatása, többnyire a filozófiai vagy pedagógiai tanszékek keretein belül (KISS, 1995, 17; VINCZE, 2011a, 171-183). 
A fővárosban a pszichológia inkább a Fővárosi Pedagógiai Szeminárium pszichológiai laboratóriumában volt jelen, ahol Révész Emil, majd a rehabilitált Nagy László vezetésével folytak képességvizsgálati eljárások részint állami utasításra, részint testületek megrendelésére. A bölcsészkaron Révész távozása után tanszéke is megszűnt, majd 1933-ban alakult újjá a Filozófiai Szeminárium részeként Lélektani Intézet néven, báró Brandenstein Béla filozófiaprofesszor felügyeletével. Ez azonban afféle segédintézmény volt a filozófia tanszékén belül, amelyet Harkai Schiller Pál magántanár vezetett (LÉNÁRD, 1991).

Szegeden Imre Sándor pedagógiaprofesszor 1926-os javaslatára állítottak fel egy második pedagógiai tanszéket, amely hosszas huzavona után PedagógiaiLélektani Tanszék elnevezéssel született meg 1929-ben, és élére Várkonyi Hildebrand került professzornak. Várkonyi érdeklődésének középpontjában a nevelői munkát megalapozó pszichológiai kérdések álltak, behatóan ismertette és interpretálta a kor nagy francia teoretikusait (Claparède, Ferrière, Piaget) (VINCZE, 2011a, 178-179).

A pécsi Erzsébet Tudományegyetemen a pedagógiai tanszék vezetője Weszely Ödön volt, aki a század elején a Fővárosi Pedagógiai Szeminárium igazgatójaként tevékenykedett, így rendelkezett ismeretekkel a kísérleti pszichológiával kapcsolatosan. Weszely már mủködése kezdetén létrehozott tanszékén belül egy pedagógiai laboratóriumot, itt vezette be a hallgatókat a pszichológiai kísérletek lefolytatásának módszereibe. Weszely Budapestre való áthelyezése után 1937-től a tudós bencés szerzetes, Bognár Cecil lett az utóda, aki érdeklődött a kísérleti pszichológia iránt, bár a pszichotechnikát, a tesztek jelentőségének túlértékelését veszélyes dolognak tartotta (VINCZE, 2011a, 181-184).

Észak-Erdély visszacsatolása és a kolozsvári egyetem újjászervezése 1940-ben annyiban változtatott a helyzeten, hogy Várkonyi Hildebrandot áthelyezték Kolozsvárra, helyére, Szegedre Bognár Cecil került, Pécsett pedig szünetelt a bölcsészkar.

A pszichológia hazai helyzetének sanyarú voltát jól összegezte Várkonyi Hildebrand nevelés-lélektani munkájának előszavában:

„Hazánkban a lélektan müvelése és hivatalos értékelése messze elmarad más nemzetek törekvései és intézményei mögött. Elég rámutatni arra a tényre ezzel kapcsolatban, hogy a lélektannak, vagy a kísérleti lélektannak nincsen egyetlen egyetemi tanszéke sem a hazai négy egyetemnek egyetlen olyan karán sem, hol a jövendö tanitók, tanárok s nevelök nevelödnek." (VÁRKONYI, 1937, 4; VINCZE, 2011a, 178-179.)

\section{A bölcsészkari elözmények}

Az egyetemi bölcsészkarokon a pszichológia főként a filozófiából nőtt ki, vagy a pedagógia melléktermékének számított. Hasonlóan a főváros egyeteméhez, Debrecenben is először a filozófiával kapcsolatban jelent meg a pszichológia oktatása. A Debreceni Tudományegyetem 1914-es megszervezéskor még nem alakult külön pedagógiai tanszék, hanem a filozófia professzorának, illyefalvi Tankó Bélának kellett a pedagógiai tantárgyakat is előadnia. 
Tankó hirdetett az 1915/16-os tanév első felében Lélektan című háromórás főkollégiumot, így ezt tekinthetjük az első pszichológiai egyetemi előadásnak Debrecenben. Ez nemcsak egyszeri alkalom volt, hanem Tankó ugyanezt a tárgyat nagyjából kétévente meghirdette eleinte 4 vagy 3 , később 3 vagy 2 órás tárgyként egészen 1946-os haláláig. Sőt az 1921/22-es tanév első felében A vallás lélektana címmel kétórás, az 1936/37-es tanév első felében A néplélektan problémái címmel egyórás mellékkollégiumot tartott filozófiai szakórái mellett.

Arra, hogy pszichológiai előadás tartását a mindenkori filozófiaprofesszor is magáénak vallotta, az is utal, hogy Tankó tanítványa és utódja, a mindössze két évig (1948-1949) a tanszéket vezető Kondor Imre is tartott főkollégiumot ebből (az első félévben Pszichológia, a második félévben Általános lélektan címmel).

Még 1916 elején a Magyar Tudományos Akadémia kiadásában megjelent Posch Jenő Lelki jelenségeink című kétkötetes pszichológiai kézikönyvét tizenöt példányban megkapta a minisztériumtól a Bölcsészettudományi $\operatorname{Kar}^{1}$, a raktáron lévő könyvek sorsáról 1924. január 26-án² úgy határozott a kari tanácsülés, hogy ezután minden évben a pedagógiai vizsgán legjobb eredményt felmutató hallgató kapjon egy-egy példányt ajándékkönyvként. A kötetek a következő tanév végétől 1932-ig kerültek kiosztásra (MUDRÁK, 2012, 43).

\section{Mitrovics Gyula és a Kisérleti Lélektani Intézet}

Négyévi kérelmezés után, 1918 júniusában a kettős tanszéket végre szétválasztották, és a megalakuló Neveléstudományi Tanszék (Szeminárium) vezetőjévé nyilvános rendes tanárként azt a Mitrovics Gyulát nevezték ki, aki korábban, 19101914 között a bölcsészkar elődjének számító Református Kollégium Bölcsészeti Akadémiáján a pedagógia és a filozófia főiskolai tanára volt.

Mitrovics a kísérleti pszichológia lelkes híve volt, műveiben egyértelműen kimutatható például Ranschburg Pál hatása. ${ }^{3}$ A pedagógia mellett esztétaként is ismert Mitrovics pszichológiai alapokra építette fel munkáit, minden munkájában jelen van a pszichológia. A fő művének számító, A neveléstudomány alapvonalai c. könyvében a nevelés fő céljának a valláserkölcsi személyiség kialakítását, fő feladatának pedig a lélek nevelését tekinti. Az értelmi, érzelmi és akarati nevelésről szóló alfejezetekben mindig ott van az alapot szolgáló lélektani folyamatok pontos bemutatása, a figyelemről és az emlékezetről szóló részek pedig kísérleti pszichológiai statisztikák, kísérletek leírásaival vannak tűzdelve (ÁDÁM és TóTH, 1994, 7; Vincze, 2011a, 190). Nem mellékesen, Mitrovics Gyula volt a Magyar Psycho-

1 BTK Jegyzőkönyvek 1915/16. tanév, VI. rendes ülés, 1916. febr. 21. 33. pont. - Vallás és Közoktatásügyi Minisztérium (VKM) 152218/1915. IV. sz. rendelet.

2 BTK Jegyzőkönyvek 1923/24. tanév, VIII. rendes ülés, 1924. jan. 26. 60. pont.

3 Kapcsolatukhoz érdekes adalék lehet, hogy Ranschburg Pál egyébként Mitrovics ötven éves tudományos működésére készített emlékkönyvben is közölt egy tanulmányt: Ranschburg Pál: Az emberi beszéd strukturáltságát feltételező tényezők törvényszerűségeiről. In BARÁNSZKY-JÓB L., BODA I., FARAGó T., VAjThÓ L. és Zombor Z. (1939) (pp. 259-308). - Idézi: Vincze, 2011a, 190, (288. lábjegyzet). 
lógiai Társaság egyik alelnöke és 1933-tól a társaság akkor alakult esztétikai szakosztályának elnöke egészen 1937-ig, a szakosztály önálló társasággá alakulásáig (VINCZE, 2011a, 151-153).

Az egyetemi előadások során Mitrovics háromórás főkollégiuma mindig valamilyen pedagógiai pszichológiai témakört ölelt fel (Az értelmi nevelés; Az érzelmek nevelése; $A z$ akarat nevelése stb.), a sok címvariáns tulajdonképpen egy jól meghatározható témakört takart. Néha adott ennek összefoglaló jelleget a címben is $(A z$ egyes tudatjelenségek szerepe a nevelésben; Az érzelmek fejlödése és irányitása a gyermekkorban; Az iskolásgyermek lélektana), speciális téma csak ritkán bukkan fel (A nyelutanitás pszichológiája - 1928/29. II. félév).

A Neveléstudományi Szemináriumon belül egy Pszichológiai Intézet felállítását javasolta Mitrovics Gyula a bölcsészkar 1925. április 28-i ülésén ${ }^{4}$, amelyet a minisztérium első körben elutasított. Mitrovics azonban nem hagyta magát, és a szeptember 7-i ülésen azzal az érvvel adta be újra kérvényét, hogy a „Pszichológiai Intézet felszerelése a pedagógiai tanszék javadalmából már rendelkezésre áll, és így semmiféle újabb kiadást már nem igényel"s. Erre már a minisztérium sem támaszthatott kifogást, és az engedélyt megadta (VINCZE, 2011b, 20).

Az „intézet” kifejezés mai szemmel egy összefoglaló nagyobb szervezeti egységet jelent, de akkor a bölcsészkarokon afféle segédintézménynek (tulajdonképpen valamiféle labornak) tekintették egy-egy intézet megalakítását, amely persze magja lehetett egy későbbi tanszéknek. Igy a Pszichológia Intézet néven megalakult, majd az 1929/30-as tanév második felétől Kísérleti Lélektani Intézet néven véglegesült egység a Neveléstudományi Tanszék (Szeminárium) alárendelt, nem önálló része volt, és mindenkori igazgatója a tanszéket vezető nyilvános rendes tanár. ${ }^{6}$

A tanszék meghirdetett óráit illetően a háromórás pedagógiai pszichológiai főkollégiumot és kétórás neveléstörténeti mellékkollégiumot kiegészítette a kétórás Szemináriumi gyakorlatok. Ezek eleinte csupán a neveléstudomány klasszikusainak olvasását jelentették, a Kísérleti Lélektani Intézet megalakulása után már a „szemináriumi” jelző „lélektani”-ra változott, többnyire szintén számtalan címvariánssal (Kísérleti lélektani/pszichológiai gyakorlatok; Gyakorlatok a pedagógiai lélektan köréböl stb.). A harmincas évek közepétől pedig már pontosabban jelöli ki ez a cím is a tanszék, illetve annak belső intézete tevékenységét: Emlékezet- és típusvizsgálatok (például 1935/36. II. félév), Kisérletek az intelligenciavizsgálatok köréból (1935/36. I. félév).

A jól hangzó intézet azonban nem alkotott valós, mai értelemben vett és anyagilag ellátott kutatószemélyzetet, hanem csupán érdeklődő hallgatók lehettek

${ }^{4}$ BTK Jegyzőkönyvek 1924/25. tanév, XIII. rendes ülés, 1925. ápr. 28. 88. pont. - Elutasítása: VKM. 82/1925. IV., illetve VKM. 42283/1925.

${ }^{5}$ BTK Jegyzőkönyvek 1925/26. tanév, I. rendkívüli ülés, 1925. szept. 7. 3/b. pont. - Elfogadása: VKM. 73094/1925. IV.

6 A debreceni pszichológusképzés 20 évéről szóló kiadványban tévesen szerepel: „Az 1926/27-es tanév első félévében létrejött a Tanárképzö Intézet, a másodikfélévben pedig ennek keretein belül [!?] megalakult az ugyancsak Mitrovics Gyula által vezetett Pszichológiai Intézet." (ÁDÁм, TóTH, 1994, 8.) - A gyakorlati tanárképzést szolgáló egyetemi Tanárképzőintézet a bölcsészkar mellé szervezett egységként alakult, Mitrovics intézetéhez semmi közvetlen kapcsolata nem volt. 
alkalmazottai díjtalan gyakornoki vagy a valamivel magasabb presztízsű fizetéstelen tanársegédi címmel. Abban az időszakban ugyanis a Bölcsészettudományi Kar nagyon kevés fizetéses állással rendelkezett, azt a keveset is a „nagyobbak”, mint például a Földrajzi Tanszék vagy a Történelmi Szeminárium vitték el, a többieknek csak díjazás nélküli státusz jutott. ${ }^{7}$

Némi jövedelempótló támogatást csupán 1936-1938 között sikerült az egyik fizetéstelen tanársegédnek (Faragó Tibornak) az Állástalan Diplomások Országos Bizottsága (Á. D. O. B.) révén szereznie (MUDRÁK, 2006, 110; VINCZE, 2011b, 22).

Mitrovics tudományos és tanári munkásságának elemzésekor Vincze Tamás kiemeli, hogy a Kísérleti Lélektani Intézet beosztottjai között a humán szakosak mellett jelentôs számban voltak matematika-fizika szakos hallgatók is, akiket eredeti végzettségük különösen a vizsgálatok során kapott eredmények kiértékelésében segítette (VINCZE, 2011a, 246).

Legígéretesebb tanítványának Mitrovics minden bizonnyal a matematika-fizika szakos végzettségủ Zombor Zoltánt tekintette, aki 1935-ben doktorált nála, diszszertációja A lélektan szerepe a pedagógiában és a rekaciós-idő pedagógiai vonatkozásai címmel jelent meg. 1933-tól két évig gyakornok, újabb két évig tanársegéd minőségben dolgozott az intézetben. „Zombor a professzor irányításával figyelemre méltó kutatásokat folytatott: átdolgozta a Sterzinger-és Roggenkampf-féle figyelemvizsgálatokat. Ezenkivuil úffajta módszert dolgozott ki a figyelem, az emlékezet és a lényeg-felismerési képesség vizsgálatára, és koordinálta azt a kisérleti figyelemvizsgálatot, amelyet az összes debreceni középiskola négy felsőbb osztályában végeztek (az öt teszt között ott volt az általa készített és átdolgozott feladat-együttes is). Így készült el a mintegy 1600 személyról 13000 adatot tartalmazó vizsgálati anyaga" (VINCZE, 2011b, 23). Zombor 1937-ben a debreceni ref. tanítóképző intézet tanára, 1943-tól a nagyváradi tanítóképző igazgatója, majd az egri főiskola tanára lett, így a pszichológiától távolabb került, bár 1939-ben a Mitrovics-emlékkönyv egyik szerkesztője, és a bevezetőben ő értékelte először mestere munkásságát.

A szintén matematika-fizika szakos végzettségű Faragó Tibor 1939-ben doktorált $A$ matematikában tehetséges tanuló c. dolgozatával. 1933-tól két évig gyakornok, majd négy évig tanársegéd volt az intézetben, és ő volt az egyetlen, akinek professzora segély jellegű állami díjazást is ki tudott eszközölni. Faragó a következő évtizedekben matematikát adott elő különböző intézményekben, végül a Kandó Kálmán Műszaki Főiskoláról ment nyugdíjba.

A többieket tekintve: „Bár jelentösebb publikációk nem füzödtek a nevéhez és nem szerzett doktori fokozatot sem, mégis illö pár szót ejteni Zilahi Ferencröl, Mitrovics első olyan gyakornokáról, aki huzamosabb ideig vett részt a Kísérleti Lélektani Intézet kutatásaiban.

7 Éppen egyik díjtalan gyakornoka (Zilahi Ferenc) állásának meghosszabbításakor 1928-ban Mitrovics szólalt fel a kari ülésen az ellen a tarthatatlan helyzet ellen, hogy egyetemi és tudományos munkát végeznek: „Egyúttal nagyon kérem a kar figyelmét arra, hogy megnevezett gyakornokunk már idáig is nagyon hasznos, sốt anyagiakban is kifejezhetö értékü szolgálatot teljesitett; azért nagyon méltányosnak tartanám, ha karunk méltóztatnék módot találni, ennek anyagi méltatására is." (BTK Jegyzőkönyvek 1927/28. tanév, XIV. rendes ülés, 1928. jún. 4. 102. pont.) - Sajnos Mitrovics kezdeményezése eredménytelen maradt, a Minisztérium nem volt hajlandó felemelni a díjas állások számát, és más forrást sem tudott biztosítani. - Idézi: VINCZE, 2011b, 21. 
Azért érdemes végigkövetni Zilahi életútjának Debrecen utáni szakaszát is, mert kiderül belöle, hogy az iskolateremtö professzor mellett eltöltött évek meghatározták a pályája további alakulását, és - a két kiemelkedö tanítványhoz, Zomborhoz és Faragóhoz hasonlóan - az intézetböl kikerülve is megmaradt érdeklödésének középpontjában a pedagógia, soha nem lett hütlen ehhez a tudományhoz.” (VINCZE, 2011b, 23-24.) Zilahi 1930-tól a sárospataki tanítóképzőben a matematika-fizika mellett lélektant is tanított, később az intézmény igazgatója is volt.

Az intézet harmadik tanársegéde, a szintén matematika-fizika szakos Ördögh László nem doktorált, de pályamunkát írt Mitrovicsnál Az intelligenciavizsgálat módszerei címmel. Ördögh 1935-től három évig gyakornok, két évig tanársegéd volt itt (VINCZE, 2011b, 24).

A díjtalan gyakornokok közül Porzsolt István neve emelhető ki elsősorban, aki később a nyíregyházi tanítóképző igazgatója, majd a főiskola neveléstudományi tanszékén föiskolai tanár volt. Gyakornoksága (1932-33) alatt foglalkozott pszichológiával, az 1936-37-es tanévben ösztöndíjjal a baseli egyetemen járt, ahol pszichológiát is tanult.

Lengyel Imre 1932-33 között volt gyakornok, később középiskolai tanár, majd az Egyetemi Könyvtár fömunkatársa lett. 1936-os disszertációja $A$ modern nyelvoktatás föbb tényezői a már meglévő nyelvi ismeretek (anyanyelv) szempontjából címmel jelent meg és részben pszichológiai alapozású. ${ }^{8}$

Nemes Elemér, aki 1940-42 között volt gyakornok, 1941-ben Hipnotizmus. Suggestio és hipnotikus hatások a nevelésben címmel doktorált Mitrovicsnál. Ugyancsak Kupán Ibolya, aki 1941-ben csupán pár hónapig gyakornok, ebben az évben A gyógyító nevelés c. disszertációjában fỏleg a lelki élet abnormitásaival és a lelki betegségekkel foglalkozott.

Nem volt az intézet gyakornoka, de szintén Mitrovicsnál doktorált 1936-ban Kósa-Szabó Erzsébet, akinek dolgozata (A gyermeknyelv pedagógiájának alapvonalai) szintén pszichológiai alapokon nyugszik.

\section{Mitrovics kontra Karácsony, Boda István szerepe}

Karácsony Sándor, a nyelvlélektan országosan ismert tudósa 1934-ben szerzett magántanári képesítést a debreceni bölcsészkaron. Eredetileg habilitációs témaköre „A neveléselmélet néplélektani alapjai” lett volna, de Mitrovics javaslatára „Az iskola nevelő munkája" tárgykörre változtatta át. Nyolc éven át magántanári előadásait szinte minden félévben nagyszámú közönség előtt tartotta. Orái az iskola akarati, érzelmi, vallásos, nemzeti és szexuális neveléséről szóltak, tehát mai fogalmakkal pedagógiai pszichológiát adott elő.

Mitrovics Gyula 1941. szeptember elején nyugalomba vonult, helyére két komoly jelölt pályázott: Karácsony Sándor, a helybeli magántanár és fülei Boda István szegedi magántanár, a kassai Kereskedelmi Főiskola tanára (MUDRÁK, 2012,

8 Ne felejtsük, hogy Mitrovics az 1928/29-es tanév második felében A nyelvtanítás pszichológiája címmel hirdetett háromórás főkollégiumot! 
44). Mitrovics lelkesen támogatta Bodát, akit a Magyar Pszichológiai Társaságból ismert, és akinek tesztekkel, kérdőíves felmérésekkel (például a következtető képesség mérésében) alátámasztott tanulmányai garanciát jelentettek volna arra, hogy továbbviszi a Mitrovics-féle kísérleti pszichológiai vonalat. Különösen jelentősnek tartotta Boda kutatásait a sajátosan magyar személyiségjegyek feltárását illetően (VINCZE, 2011a, 119, 167, 190) .

Míg Mitrovics Bodát illetően elfogult volt és magasztalta, Karácsonyt pedagógiai nihilizmussal, módszertelenséggel vádolta, és elérte, hogy Bodát jelöljék professzornak. A jelölés ellen többen különvéleményt nyújtottak be a miniszterhez, végül 1942 júniusában Horthy kormányzó Karácsonyt nevezte ki a pedagógia professzorának Debrecenbe.

\section{Benedek László}

Az 1918 őszén alapított, de csak 1921-ben megindult Orvostudományi Karon az 1921 októberében akkor létesült debreceni Ideg- és Elmekórtani Klinika igazgatóprofesszorává a volt kolozsvári egyetem fiatal tanársegédét és magántanárát, a Lechner Károly-tanítvány Benedek Lászlót nevezték ki. Benedek sokoldalú egyéniség volt, széles körủ munkásságában elsősorban agypatológiai, neuropszichiátriai témakörökben alkotott maradandót, de jelentősek törvényszéki elmeorvostani, pszichopatológiai, klinikai lélektani írásai is.

Benedek 1928-ban részt vett a Magyar Pszichológiai Társaság megalapításában, és az első elnök, Ranschburg Pál hároméves ciklusa letelte után, 1931 áprilisában a társaság elnökévé választották ${ }^{10}$. Ezt a tisztséget három cikluson át, egészen 1939-ig viselte (BíRó, 2008, 156-161). Figyelemre méltó, hogy a Társaság második elnökének egy debreceni professzort választott, ez mindenképpen Benedeknek a pszichológiai szakmai körökben lévő elismertségére utal.

Az ő javaslatára 1932 januárjában a debreceni Tisza István-Tudományegyetem Orvostudományi Kara alapító tagként egyhangúlag és testületileg belépett a Magyar Pszichológiai Társaságba. ${ }^{11}$

Mind a pesti tudományos társaságban, mind egyetemi munkájában jól együtt tudott működni Mitrovics Gyula debreceni pedagógiaprofesszorral (SzÁLLÁsI, 2000, 21). Mitroviccsal és Boda Istvánnal, a Magyar Pszichológiai Társaság főtitkárával közösen 1932-ben egy elaborátumot (javaslattervezetet) készítettek a lélekta-

\footnotetext{
9 Mitrovics Gyula Boda művei közül a Bevezetô a lélektanba c. munkáját azért is emelte ki, mert ez bizonyította szerinte, hogy egy pszichológiai szakíró a legalkalmasabb a pedagógiai tanszék betöltésére: „Tekintve azt a belső kapcsolatot, amely lélektan és pedagógia, valamint a nevelói gyakorlat között fennáll, Bodának ebben a könyvében elért eredményeit pedagógiai szempontból nem lehet eléggé méltányolnunk..." Mitrovics Gyula véleményes jelentése. BTK Kari Jegyzőkönyvek 1941/42. tanév, VI. rendes ülés, 1942. febr. 11., 107. szám melléklete. - Idézi: VINCZE, 2011a, 190-191.

${ }^{10}$ A Magyar Psychológiai Társaság elnökévé való megválasztását a debreceni orvosi kar ülésén is bejelentették, és kartársai ezen alkalomból üdvözölték (Orv. Jegyzőkönyvek 1930/31. tanév, XVIII. rendes ülés, 1931. ápr. 23. napirend elött).

11 Orv. Jegyzőkönyvek 1931/32. tanév, VIII. rendes ülés, 1932. jan. 28. 47[/11.] pont.
} 
ni ismeretek terjesztése, valamint nagyobb fokú nemzeti és kulturális hasznosítása céljából.

Ebben Benedek nagyon fontosnak tartotta a lélektan alkalmazását a pszichiátriában. Külön is kiemelte a pszichológiai tesztek használatát, mert ezek „az elmegyógyászatnak is nagy segitségére vannak. Egyrészt a veleszületett és szerzett értelmi fogyatékosságok eseteiben bizonyos rang-rendbe való osztályozást megengednek, és ezáltal az értelmi dekompozíció összehasonlítására alapot adnak, másrészt ugyanazon egyéneknél az esetleges progressziók fokára következtetni engednek."

Itt Benedek rátért a saját klinikáján használt pszichológiai vizsgálatokra:

„Amióta a paralysis progressivaának fertözéses kezelése kapcsán a remissziók tetemesen megszaporodtak, azóta mint Ranschburg, majd Kaufmann s mások, úgy mi is minden esetben összehasonlító vizsgálatokból kiséreljük megállapítani a javulások fokát. E célból a BinetSimon-, Éltes-, Rossolimo-, Ranschburg-, Ziehen-, Ebbinghaus-, Heilbronner-, Masselon-, Finkh-, Anton-, Hartmann-, Henneberg-, Müller-, Ganther-féle próbákat szoktuk alkalmazni, amelyeket kivihetöségǚ esetén egyenként zártosztályi vagy pszihózisra gyanús betegeinknél, klinikánk fennállása óta (1921), majdnem kivétel nélkül hasznositottunk. [...]

Nem jelentéktelen az a segítség, amelyet a kísérleti pszichológia a törvénykezésnek és a törvényszéki elmekórtannak nyújtott a vallomástétel értékének kutatása által. A figyelem ébersége, terjedelme, az észrevevés, megjegyzö- és reprodukálóképesség, a térnek, idönek becslése, a sugalmazhatóság módszeres vizsgálattal állapíttattak meg. Idevonatkozóan W. Stern, Laffa, Sommer, Ranschburg, Bernstein, Bogdanoff, E. Bernheim és mások példái után számos közlés látott napvilágot. Optikai és akusztikai benyomásokra adott reakcióknak ideje, az exponált megfigyelési ingertárgyak újrafelismerése, vetített diapozitíveknek felfogása és reprodukálása, [...] élénk, váratlan indulatokat produkáló jeleneteknek leírása szolgáltatta a kiterjedt kisérleti anyagot." (BENEDEK, BODA, MitrovicS, 1932, 10-11, kiemelés az eredetiben; SíRó, 2001, 44-45.)

Benedek professzor hozzáállását a pszichológia fontosságának kérdéséhez Pisztora Ferenc a Benedek tudományos munkásságát feldolgozó tanulmányában így foglalta össze:

„[Benedek László számára] nyilvánvaló, hogy mind a lélektannak a tudományok sorában öt megilletö középponti jelentösége - ami azonban teljes gazdagságában mindmáig rendszerint fel nem ismert -, mind pedig a helyes lélektani felismeréseknek nagy gyakorlati, közösségi-kulturális értéke - még a benső kormányzati-közigazgatási, vagy a külpolitikaidiplomáciai, sőt a gazdasági élet terén is - az értelmes emberi elörelátás számára egyenesen parancsolólag írja elő a lélektani ismeretek és helyes felismerések fejlesztésének és terjesztésének tudománypolitikai, valamint nemzetvédelmi, nemzetfejlesztési és nemzetgazdasági kötelességét." (PISZTORA, 1988, 452.)

Református vallásosságából és talán a debreceni kálvinista légkörből kifolyólag erős volt benne az individualizmus, a személyiség szabad fejlődése iránti hangsúlyozott igénye. ${ }^{12}$

12 „Az individualitás sorvadásában a kultúra legnagyobb veszélyét kell látnunk! [...] Úgy tetszik, mintha általában a személyiség kikülönbözödött értékeinek a jelen idők nem kedveznének. [...] A mechanizált üzemi részletmunkán kívül, a kapitalista országokban a személyiség kibontakozását az ipariasodás, a közlekedési és közlési technika maga is hátráltatja, mert az emberi életet mindinkább közös, kényszerített együttrezgésre hozza. A technikai fejlödésnek legmagasabb foka sem járul hozzá magában véve a belső valódi kultúrának emeléséhez, Az utóbbi az érzelmi élet 
Az Idegklinikán ekkoriban működött egy pszichológiai laboratórium, amelyet Máday István tanársegéd vezetett. A laboratórium működéséről és felszereltségéről egy 1930-as jelentésből kaphatunk képet:

„A klinikán két helyiség áll a kisérleti psychológia rendelkezésére 1923 év óta. A kisegito” iskolába felvett növendékek vizsgálatát végezzük el minden esetben különböző értelmességi vizsgálati próbákkal, elsősorban a Binet-Simon-eljárással. Egyes növendékeknél különbözö irányban képesség vizsgálatok is folynak. A pszichológiai laborban emellett képesség vizsgálatok szempontjából tudományos vizsgálatok is folynak, és a laboratórium felszerelés számos kísérleti eszközzel rendelkezik." (SíRÓ, 2001, 45-46.) ${ }^{13}$

Benedek László meghirdetett egyetemi óráiban azonban cím szerint nem lehet nyomát találni pszichológiai érdeklődésének, hiszen más klinikaigazgató profeszszorhoz hasonlóan klinikai fötárgyát (Ideg-és elmegyógyászat) adta elő heti 5 órában (5×1 óra), amelyhez gyakorlat (Ideg-és elmegyógyászati kórjelzéstan / diagnostica) társult. Mindenesetre feltételezhető, hogy az orvosi pszichológia is része volt ennek a főkollégiumnak.

\section{Máday Istuán és Pap Zoltán}

Az Ideg- és Elmeklinika megalakulásától, 1921-től kezdve hét éven át az első tanársegédi pozíciót marosi Máday István töltötte be Benedek mellett. Valószínűleg professzora szellemi nyitottságának és gyakorlatiasságának köszönhette, hogy őt választotta helyettesének és klinikája vezető tanársegédének. (Máday korábban dragonyostiszt, majd a prágai élettani intézet tanársegéde, ezután katonaorvos, illetve községi orvos is volt.)

Máday Istvánt a magyar individuálpszichológia megteremtőjének és fő képviselöjének tartják (ARATó és Kiss, 1991, 91-95; Síró, 2001, 46-52). Még Bécsben lett az individuálpszichológia atyjának, Alfred Adlernek barátja és tanítványa.

Pályája első éveiben állatlélektannal foglalkozott, különösen a lovak szellemi, tájékozódó képességét és érzelmi életét kutatta. Számos tévhitet megcáfolt a „gondolkodó” állatokkal kapcsolatban (például a kutya vagy a ló „számoló” képessége).

Az első világháború után érdeklődése a pályaválasztás kérdése felé fordult, szerinte az embereket adottságaik, képességeik szerint kell elosztani a munkahelyekre, ezért pályaválasztási tanácsadók alkalmazását szorgalmazta. A pályaválasztás lélektanáról írott tanulmányát Benedek professzor is kiemelte Máday magántanári pályázatának értékelésékor: „szerzőnek ez az 1912-i berlini lélektani kongresszuson tartott elöadása nem csupán a jelen lévő Münsterberg professzornak, a psychotechnika megteremtöjének helyeslésével találkozott, hanem ez az elöadás Európában is úttörönek bizo-

mélyítése nélkül el nem képzelhetö. Ennek a belső egyéni kultúrának mélyítése, a mai kornak egyik legfontosabb feladata, mert csak ez egyensúlyozhatja ki a lélektelen technikai és ipari haladás által okozott eltolódást. A mai Szovjetoroszországban a fiatal generációt is a kollektív munka egyhangú homlokvonalába kényszerítik bele, amelyben éppen az értéket jelentő egyéni vonások mindinkább elmosódnak.” (BENEDEK, 1932, 13-14. - Idézi: PISZTORA, 1988, 445.)

13 A megadott levéltári hivatkozás (Hajdú-Bihar megyei Levéltár, VIII. 9/b. [= 10/b.] 297/1929-30. oksz.) téves! 
nyult, amennyiben 1908 óta csakis Amerikában foglalkoztak a pályaválasztás lélektanával, s a kérdés fontosságát Európában csak 1912 után ismerték fel."14

A pályaválasztás kérdésével kapcsolatban különösen szorgalmazta a hadiárvákkal és a hadirokkantakkal való foglalkozást, hiszen az első világháború után ez új és nagyszabású jelenségként tűnt fel a különböző országokban. A hadiárvákkal való foglalkozása vitte az akkoriban kialakuló gyermeklélektani kutatásokhoz, illetve a gyermektanulmányi mozgalomhoz (DEÁK, 2000, 236).

1927-ben megalapította a Magyar Individuálpszichológiai Egyesületet, amelynek elnöke lett (az alelnöki tisztet kérésére professzora, Benedek vállalta el). 1928 tól több budapesti nevelési tanácsadó intézményben is dolgozott, a pályaválasztási kérdések megoldásához kívánt segítséget nyújtani az adleri tanok gyakorlati alkalmazásával.

A Magyar Szülők Szövetségének Gyermekvédelem c. havi folyóiratát 1933-1937 között együtt szerkesztette a sajátos pszichológiai rendszert kifejlesztő Karácsony Sándorral, aki 1942-ben Mitrovicsot követte a debreceni pedagógiai tanszék élén. Mádaynak minden bizonnyal lehetett hatása Karácsonyra, aki a fent említett folyóiratban több, az individuálpszichológiai szemlélethez közel álló írást is publikált (LÁNYI, 2000, 36).

Mádayt 1927-ben a debreceni orvosi karon „Általános psychiatria különös tekintettel a psychopathologiára” tárgykörből magántanárrá habilitálták (érdekes, hogy már 1924-ben magántanári képesítést kívánt szerezni, de akkor leszavazták, és elutasították). Ezután minden tavaszi félévben szorgalmasan megtartotta Általános psychopatologia címmel meghirdetett előadását egészen 1949-ig, amikor is megszűnt a magántanári intézmény. Még az utolsó előtti félévben, 1948 őszén (az egyetemi reform és az orvosképzés átalakításával kapcsolatban) Mélylélektani gyógyító módszerek címmel is hirdetett speciálkollégiumot.

Benedek másik pszichológia iránt érdeklődő tanítványa Pap Zoltán volt, aki sok éven át töltött be gyakornoki, majd címzetes tanársegédi státuszt mestere mellett. A negyvenes évek első felében a visszacsatolt Kassán, majd 1945 után Debrecenben volt ideggyógyász főorvos. A debreceni orvosi karon 1936-ban „Általános psychiátria" tárgykörből magántanárrá habilitálták.

Kedvenc témája a tömeglélektan és ezen belül is a szuggesztió volt, amelyekben tetten érhető a francia filozófusnak, Gustave LeBonnak a szociálpszichológia kialakulását befolyásoló tömeglélektani felfogása is.

Benedek professzor a magántanári pályázatának bírálatában ki is emelte: „ $A$ tömeg lélektani sajátságainak jellemzése alapján rámutat azokra a pszichés feltételekre, amelyek az emberi tömegeket nagyfokban suggeralhatóvá teszik. Ilyenek a collectív tudat személytelensége, a felelótlenség, a képzeleti tevékenység és az indulatok túlcsapongása, a logikai itélömüveletek hiánya és szerfelett fokozódó hiszékenység. A collectív suggestio ellenállhatatlan erejének igazolására lélektani elemeire bontja a gyermek-keresztesháború, a középkori démonhit, a megszállottsági járványok, az ördögüzés, az inquisitio, a jansenismus, a németországi vitustánc járvány, az olaszországi tarantizmus, valamint az Oroszországban vallásos

14 Benedek László professzor bírálata. Orv. Jegyzőkönyvek 1926/27. tanév, XVII. rendkívüli ülés, 1927. máj. 30. 105/1. pont melléklete. - Idézi: Síró, 2001, 49. 
secták keretében kifejlödött öngyilkossági tömegpsychosisok mozgató erőit. Megállapítja, hogy a collectív suggestiók meghamisitják az észrevevéseket. Ha az indulatok elragadják a lelket és a képzelet szârnyalása fölé kerül az értelem következtetéseinek, a hiszékenység és a suggerálhatóság lehetöségei szinte korlátlanok."'5

Pap Zoltán 1936-tól kezdve kétévente tartott Általános psychiátria néven előadást, majd 1947 első felétől kezdve minden félévben Orvosi pszichológia, illetve Orvosi lélektan címmel egy másik előadást is. Mindezek alapján az orvosi karon 1947. szeptember 1-jétől 1949. április 30-ig az orvosi pszichológia tárgy szakelőadója (mb. előadója) is volt.

\section{Karácsony Sándor és a Társaslélektani Intézet}

Karácsony nyelvészeti és magyarságot nevelő / mentő munkássága sajátos pszichológiai alapokon nyugszik, amelyet ma már leginkább a társaslélektan és a fejlődéslélektan kombinációjaként lehetne meghatározni (LÁNYI, 1995, 106-134; LÁNYI, 2000). Karácsony felfogásában a nyelv, az emberi beszéd a pszichológiából kiindulva válik csak érthetővé. A pszichológia nála nem az egyént vizsgálja, hanem az emberek közösségének lelki sajátságaira alapoz. Ennek a közösségnek az egymás felé való viszonyulási formája a társaslélektan. Ráadásul rendszerében a lélektan vegyül számos más tudománnyal (nyelvészet, pedagógia, néprajz, irodalom stb.), amelyet számos személyes elemmel bővít, így lesz rendszere saját életérzése és a magyarságnak tulajdonított jellegzetességek együttese sajátos „magyar társaslélektan”, ami szerinte: „olyan praktikus program, amely rendezi a világot körülöttünk: azaz megmutatja helyzetünket és helyünket a világban." (KARÁCSONY, 1944, 29; LÁNYI, 1995, 118.) Mai értelmezésben: „Karácsony Sándor társaslélektana a hazai szociálpszichológiaitársadalomlélektani gondolkodás egyik szerves elözményének tekinthetó." (LÁNYI, 1995, 113.)

Érdekes módon Karácsony Sándor professzorként meghirdetett egyetemi föés mellékkollégiumaiban cím szerint nem nagyon lehet találni pszichológiai órákat (MUDRÁK, 2012, 44-45) ${ }^{16}$, de aki ismeri a munkásságát, biztos lehet abban, hogy ezek az elvileg pedagógiai témák is az ő társaslélektani felfogása szerint lettek interpretálva. Erről árulkodik az is, hogy szemináriumát az 1945/46-os tanév II. felében Fejlódéslélektani problémák címmel hirdette meg. Kiskollégiumai az 1947/48as tanév I. felében $A$ lélektan fókérdései, két félévvel később pedig $A$ nevelö lélektana címeket viselték. ${ }^{17}$

15 Benedek László professzor bírálata. Orv. Jegyzőkönyvek 1935/36. tanév, XIII. rendkívüli ülés, 1936. máj. 29. 115. pont melléklete. - Idézi: Síró, 2001, 54-55.

16 „Karácsony 3 vagy 2 órás egyik főkollégiumában valamely nagyobb pedagógiai tárgykört adott elő (Pedagógia és filozófia, A tanitás problémái, Didaktika stb.), másik 2 órás főkollégiumában neveléstörténetet oktatott főleg jeles pedagógusok személye köré csoportosítva (Herbart, Pestolazzi, Comenius, Rousseau, Apáczai Csere János stb.). Szemináriumát Pedagógiai enciklopédia címszó alatt hirdette meg [...]. A második világháború után aktuális politikai-pedagógiai kérdésekről tartott még 1-1 órás kiskollégiumokat is (A tanárképzés reformja, Az egyetem és az akadémia reformja, Cserkészet)."

17 Az 1947/48. I. félévi A lélektan fókérdései c. kollégiumát mint a filozófiai tanszék helyettes vezetője hirdette meg. 
A Neveléstudományi Szeminárium mellett működő Kísérleti Lélektani Intézet rövid szünet után átalakult Társaslélektani Intézetté, amelyet Karácsony 1942 novemberében jelentett be a kari ülésen. ${ }^{18}$ Mivel a költségvetésben ez nem jelentett változást, a minisztérium tudomásul vette a dolgot.

Mitroviccsal szemben Karácsony nem tudott fizetéses állást szerezni a Társaslélektani Intézetnek, az csak a Neveléstudományi Tanszéknek volt. Eleinte az intézetnek egyetlen címzetes tanársegéde volt (Lükő Gábor), majd 1945 után jön ehhez még egy, majd két díjtalan gyakornok, már jóval kevesebben, mint az elöd intézménynél (MUDRÁK, 2012, 111).

Az etnográfus Lükő Gábor, a Déri Múzeum munkatársa 1943-tól a megszüntetésig, 1950-ig volt az intézet fizetéstelen (címzetes) alkalmazottja, eközben 1945ben magántanárrá is habilitálták. Magántanári órái minden félévben az irodalmi és zenei nevelés folklorisztikus alapjairól szólt, nyilvánvalóan pszichológiai megközelítésben. A készülődő átalakulás jegyében az 1948/49-es tanév II. félévében szűkebb szakmai előadása mellett Fejlődéslélektan előadást is tartott IV. éveseknek heti két órában.

Az intézet másik tanársegéde, Komjáthy István leginkább a Mondák könyve c. összeállításáról ismert, viszont $A$ tehetségkutatás magyar módja címü doktori disszertációját 1944 nyarán védte meg Karácsonynál (VINCZE, 2011b, 27).

Bár nem a Társaslélektani Intézet, hanem a Neveléstudományi Szeminárium tanársegéde volt Kovács Ferenc, aki utóbb Fabricius-Kovács Ferenc lett, a nyelvtudomány jeles képviselője, és a tudományos világban leginkább ő tudta képviselni mestere néplélektani-társaslélektani eszméit; igaz, csak nyelvészeti vonatkozásban: „1967-ben két olyan tanulmányt is publikált, amelyekben Karácsony nyelvfelfogását és az abból levezethetö kommunikációs rendszert nevezte meg a nyelvröl való gondolkodása kiindulópontjaként. E két irásában magától értetödö természetességgel használta a karácsonyi fogalomrendszer olyan elemeit, mint például viszonyulás (ebben határozta meg a nyelv funkcióját), másik ember, autonóm ember." (VINCZE, 2011b, 29. ${ }^{19}$

A bölcsészkar magántanára volt 1946-tól Kiss Árpád, akinek habilitációja ugyan neveléstudományi témára szólt, de pszichológiai órákat is tartott: $A$ functionális lélektan hatása a nevelésre (heti 2 óra, 1947/48. II. félév). Az oktatás átalakulásának jegyében az 1948/49. tanév II. felében heti 2 órás Neveléslélektan előadást tartott, amihez szintén 2 órás gyakorlat is tartozott.

Kiss Árpád mint Piaget-fordító és interpretátor is figyelmet érdemel: 1947-ben az öntevékenység és az önfegyelem összefüggésének Piaget-féle felfogását ismertette, ${ }^{20}$ ugyanebben az évben egy tanulmánykötetet szerkesztett Piaget munkássá-

\footnotetext{
18 „A pedagógiai szeminárium mellett müködő s elödöm, dr. Mitrovics Gyula ny. r. tanár úr nyugalomba vonulásakor megszüntetett Kisérleti Lélektani Intézet helyett ugyancsak a pedagógiai szemináriummal kapcsolatban Társaslélektani Intézet felállitását kérem." (BTK Jegyzőkönyvek 1942/43. tanév, III. rendes ülés, 1942. nov. 11. 43. pont)

19 FABRICIUS-KOVÁCS Ferenc két nyelvészeti-társaslélektani munkája: Jelentés, társaslélektan, kommunikáció-elmélet. Magyar Pszichológiai Szemle, 1967/3, 331-346. és A jelentés és a „másik ember”. Kortárs, 1967/8, 1273-1282.

20 Kiss Árpád (1947). A munkáltatás. (Köznevelés Könyvtára I.) Budapest, 13-22.
} 
gáról, ${ }^{21}$ majd 1948-ban elsőként közölt eredeti Piaget-szöveget (mintegy hetven oldalt $A$ gyermek erkölcsi itélete címủ könyvbőll22 (MÉREI, 1989, 115).

\section{Kiss Tihamér}

Jelentőségénél fogva külön kell szólni a gyermekpszichológus Kiss Tihamérról. Az 1940-es évek első felében a sepsiszentgyörgyi tanítóképző tanára volt és 1943-ban kolozsvári egyetem bölcsészkarán „A gyermekkor lélektana” tárgykörből magántanárrá habilitálták. Romániából való kényszerủ távozása után Debrecenbe jött, ahol a Református Kollégium tanítóképzőjének tanára és igazgatója lett. Emellett 1947 júliusától 1950 eleji megszüntetéséig az általa megszervezett debreceni Állami Gyermeklélektani Állomás vezetője is volt. 1947-ben kolozsvári magántanári habilitációját átvette a Debreceni Tudományegyetem.

Pszichológiai tanulmányait és tudományos kutatásait Szegeden Várkonyi Hildebrandnál, illetve állatpszichológiából itt Gelei József állattani professzornál végezte, majd ösztöndíjjal Genfben, a Rousseau Neveléstudományi Intézetben Jean Piaget kutató asszisztenseként gyermeklélektani vizsgálatokat folytatott (PAPPNÉ KÉSMÁRKI, 1991). A XX. század legnagyobb gyermekpszichológusának, Piaget-nek - Binét Ágnes mellett - másik magyar tanítványa, aki az elsők között igyekezett mestere munkásságát népszerüsíteni Magyarországon (MéREI, 1989, 114-115).

Tudományos munkássága fóként a gyermekek tárgy- és térszemléletére koncentrálódott, ezekről tanúskodnak magántanári előadásainak címei is: Az iskolás gyermek világszemlélete (1947/48. II. félév); A gyermek prekauzális gondolkodása (1948/49. I. félév). A készülődő átalakulás, a felsőoktatási reform jegyében neki is részt kellett vennie általános pszichológia oktatásában a többi magántanár és tanszéki beosztott oktatóhoz hasonlóan, ő az Intelligencia-vizsgálatok módszerei címmel tartott heti egyórás kollégiumot az 1948/49-es tanév I. félévében, míg a másodikban szűkebb (magántanári) témáját (A gyermeki gondolkodás fejlödése) IV. éveseknek, gyakorlat formájában tartotta meg.

\section{Kitekintés}

Érdekes módon az 1948-49-es tanév két félévében a pszichológiai órák száma nőtt, már nemcsak magántanári, hanem kötelező előadásokkal, amelyeket gyakorlat egészített ki. Több oktató tartotta ezeket (Kiss Árpád, Kiss Tihamér, Lükő Gábor), ami már-már fejlődésnek is tűnhet, amelyet azonban hirtelen, 1950-től a pártállami berendezkedés merev elzárkózása és ellenséges hozzáállása miatt a pszichológiai háttérbe szorulása követett.

21 Kiss Árpád (szerk.) (1947). A tanitás és az értelmi fejlesztés. Budapest.

${ }^{22}$ KISs Árpád (szerk.) (1948). Nevelés és neveléstudomány - Pedagógiai olvasókönyu. (Nevelők Könyvtára 3.) Budapest, 1227-1249. 
Ezt az időszakot az oktatott tartalmak beszűkülése jellemzi, mindent eluralt a pavlovi pszichológia, a szovjet lélektan eredményeinek kivonatolt ismertetése. (Úgy gondolták, hogy az egzakt lélektan kialakításához Pavlov reflexológiáján, a magasabb idegtevékenységek objektív mérésén keresztül vezet az út.) Valódi pszichológiai felkészítésben nem részesültek a tanár szakos hallgatók, a magyar pszichológia addigi irányzatairól mélyen hallgattak. A kor legnagyobb pszichológusai vagy kitelepítésben (Kornis Gyula), vagy a szakma peremén (például Várkonyi Hildebrand) voltak, az átfogó pszichológiai elméletek helyét a töredékes, hézagos, erősen szelektált és átideologizált lélektani olvasatok vették át. A debreceni egyetemen folyó lélektanoktatásra is ez hatott. Ki sem ejtették a század legnagyobb pszichológusainak a nevét, úgy kaptak diplomát a végzett tanárok, hogy az individuálpszichológiát (amelynek hazai népszerűsítője Máday volt) és a jungi analitikus pszichológiát még csak hírből sem ismerték.

A Karácsony eltávolításával vezető nélkül maradt Neveléstudományi Intézetet átszervezték Pedagógiai Intézetté, de új professzor kinevezése hosszas huzavonába torkollott, csak 1951 szeptemberében nevezték ki Jausz Bélát, a volt gyakorló gimnáziumi tanárt és minisztériumi szakpolitikust tanszékvezető docenssé.

A gyakorlatias, reálisan gondolkozó Jausz mellett előbb külső előadóként Kiss Tihamér tartott Általános lélektant, majd 1954-től kinevezett tanársegéddel (Ádám Péter) képviseltette magát a pszichológia. Az ekkoriban életbelépett új tanterv már tartalmazott 1-1 félévnyi, kétórás általános, illetve fejlődés- és neveléslélektant. 1959-től beindult a pedagógiaszakos nappali és levelező képzés, ezért még két pszichológus oktató (Surányi Gábor docens és Nádudvari Imréné Prokofjeva Lidia tanársegéd) lett alkalmazva. Jausz tanszékvezetésének utolsó időszakában alakult meg a pszichológiai szakcsoport, amely az önálló tanszéki keret alapjává vált (ÁDÁm és TóTH, 1994, 10-11).

Összefoglalásként elmondható, hogy Jausz Béla mindent megtett, amit abban az időben a pszichológia túléléséért az adott körülmények között meg lehetett tenni. Mindez kellett ahhoz, hogy a Jauszt 1966-ban követő Kelemen László vezetése idején 1970-ben megalakulhasson az önálló debreceni Pszichológiai Tanszék.

\section{IRODALOM}

ÁDÁм P. és TóTH L. (1994). A pszichológiai története a Debreceni Egyetemen. In KovÁcs Z. (szerk.), A debreceni pszichológusképzés 20 éve (5-29). Debrecen: Kossuth Lajos Tudományegyetem Pszichológiai Intézet.

ARATó O. és Kiss Gy. (1991). Az individuálpszichológia és hatása Magyarországon. (Pszichológia - nevelőknek) Budapest: Tankönyvkiadó.

BARÁNSZKY-Jób L., BodA I., FARAGÓ T., VAJThÓ L. és Zombor Z. (1939). Mitrovics-emlékkönyv tudományos müködésének ötvenedik évfordulójára. Budapest: Csáthy Ferenc Egyetemi Könyvkereskedés.

BENEDEK L. (1932). A világválság néplélektani okairól. (Elnöki megnyitó) Magyar Psychológiai Szemle, 4, 5-14. 
Benedek L., Boda I. és Mitrovics Gy. (1932). A Magyar Psychológiai Társaság Elaborátuma a lélektani ismeretek terjesztése és nagyobbfokú nemzeti-kulturális értékesítése tárgyában. Budapest: A Magyar Psychológiai Társaság kiadása.

Bíró V. (2008). A Magyar Pszichológiai Társaság története évszámokban (1928-2008). In GyÖngYÖSINÉ KISS E. (szerk.), Nyolc évtized - Tanulmányok a Magyar Pszichológiai Társaság életéből (156-161). Budapest: Magyar Pszichológiai Társaság.

DEÁK G. (2000). A magyar gyermektanulmányi mozgalom története I. Budapest: A Fővárosi Pedagógiai Intézet, a Magyar Pedagógiai Társaság és az Országos Pedagógiai Könyvtár és Múzeum kiadása.

KARÁCSONY S. (1944). A magyarok kincse (értékrendszer és axiológia). (A neveléstudomány társas-lélektani alapjai 3/1.) Budapest: Exodus Kiadó.

KIss GY. (1995). A hazai pszichológiatörténeti kutatások eredményei. In Kiss GY. (szerk.), Pszichológia Magyarországon (16-17). Budapest: Országos Pedagógiai Könyvtár és Múzeum.

LÁNYi G. (1995). Szociálpszichológia vagy „magyar társaslélektan”? - Karácsony Sándor társaslélektani rendszeréről. In KIss GY. (szerk.), Pszichológia Magyarországon (106-134). Budapest: Országos Pedagógiai Könyvtár és Múzeum.

LÁNYI G. (2000). Magyarság, protestantizmus, társaslélektan - Hagyomány és megújulás konfliktusa Karácsony Sándor életmüvében. Budapest: Osiris Kiadó.

LÉNÁRD F. (1991). Az egyetemi Lélektani Intézet 1932-1947 között végzett munkájáról. In KISS Gy. (összeáll.), Tanulmányok a magyar pszichológia történetéből (37-55). Budapest: Akadémiai Kiadó.

MÉrei F. (1989). Gyermeklélektan és ismeretelmélet: Piaget életműve. In MÉrEI F., Freud fényében és árnyékában (85-117). Budapest: INTERART.

MUDRÁK J. (2006). Gyakornokok, tanársegédek, adjunktusok, intézeti tanárok, Á.D.O.B. gyakornokok és beosztott gimnáziumi tanárok a Bölcsészettudományi Karon (19211950). In Hollósi G. (szerk.), Közlemények a Debreceni Tudományegyetem történetéboól IV (110-130). Debrecen: DE BTK Történelem és Néprajzi Doktori Iskola.

MudRÁk J. (2012). A Debreceni Tudományegyetem Bölcsészettudományi Karának története (19141949). Debrecen: Debreceni Egyetemi Kiadó.

PAPPNé KéSMÁRKi E. (1991). Kiss Tihamér munkássága. Debrecen: A Kölcsey Ferenc Tanítóképző Főiskola Könyvtárának kiadványa.

PiszTORA F. (1988). Benedek László élete, személyisége és életművének társadalom- és kulturpsychiátriai, psychológiai és eugenikai vonatkozásai. Ideggyógyászati Szemle, 41, 441-456.

Síró B. (2001). Fejezetek a debreceni Ideg- és Elmegyógyászati Klinika történetéböl I. Debrecen: Debreceni Egyetem Orvos- és Egészségtudományi Centrum.

SzÁllási Á. (2000). Dr. Benedek László (1887-1945). (A debreceni orvosképzés nagy alakjai 16.) Debrecen: Debreceni Orvostudományi Egyetem.

VÁrkonyi H. (1937). Bevezetés a neveléslélektanba. (Pedagógiai Szakkönyvek 2/b. kötet) Budapest: Országos Középiskolai Tanáregyesület.

VINCZE T. (2011a). Karrierutak és iskolateremtés a XX. század első felének magyar neveléstudományában. (Mitrovics Gyula pályájának és szakmai mühelyének kvalifikációtörténeti nézöpontú bemutatása) PhD-értekezés, Debrecen. 
VIncze T. (2011b). Pedagógiai kutatások a Debreceni Egyetem első évtizedeiben. In PuszTAi G. és Németh N. V. (szerk.), Útközben (17-32). Debrecen: Debreceni Egyetem Neveléstudományi Doktori Program.

\title{
PSYCHOLOGY AT THE UNIVERSITY OF DEBRECEN \\ IN THE FIRST HALF OF THE 20TH CENTURY
}

\author{
MUDRÁK, JÓZSEF
}

High quality researches were done on psychology at Faculty of Arts and Faculty of Medicine of Debrecen University in the first half of 20 th century and psychological courses were initiated in the university studies of that age.

Professor of neurology and psychiatry, László Benedek was the president of the Hungarian Psychological Association between 1931 to 1939, however Gyula Mitrovics, who was professor of pedagogy in Debrecen in same time, was filled to one of the vice-presidents. After Mitrovics, Sándor Karácsony succeeded in professorship, who made a special psychological system, which have a keen interest in the academic world up to present day. For the assistance of those departments, Tihamér Kiss (privat-docent next to Karácsony) was a researcher of child psychology and the first popularizer of psychologist Piaget in Hungary; István Máday (pirvat-docent next to Benedek) was the founder of Hungarian individualpsychology and the most important disciple of psychologist Adler.

For these reasons, Debrecen deservedly took place among workshops on psychological researches in the first half of 20th century.

Key words: History of psychology in Hungary, Debrecen, University of Debrecen, Gyula Mitrovics, László Benedek, Sándor Karácsony, Tihamér Kiss, Istuán Máday, Zoltán Pap 